\title{
Role of Myeloperoxidase in the Killing of Staphylococcus aureus by Human Neutrophils: Studies with the Myeloperoxidase Inhibitor Salicylhydroxamic Acid
}

\author{
By JOHN M. HUMPHREYS, ${ }^{1}$ BERNARD DAVIES, ${ }^{1}$ C. ANTHONY HART ${ }^{2}$ \\ AND STEVEN W. EDWARDS ${ }^{1 *}$ \\ Departments of Biochemistry ${ }^{1}$ and Medical Microbiology ${ }^{2}$, University of Liverpool, PO Box 147, \\ Liverpool L69 3BX, UK
}

(Received 24 October 1988; revised 9 January 1989; accepted 30 January 1989)

\begin{abstract}
We have used salicylhydroxamic acid (SHAM) to inhibit intraphagosomal myeloperoxidase activity in order to evaluate the role of this enzyme in the killing of Staphylococcus aureus by human neutrophils. $50 \mu \mathrm{M}$-SHAM reduced the luminol-dependent chemiluminescence response stimulated during phagocytosis of unopsonized latex beads and opsonized $S$. aureus by over $80 \%$ and $60 \%$, respectively. When opsonized $S$. aureus were incubated with neutrophils, $45 \%$ were killed within $15 \mathrm{~min}$ incubation and $60 \%$ by $1 \mathrm{~h}$. However, in neutrophil suspensions incubated with $50 \mu \mathrm{M}$-SHAM, only $13 \%$ were killed by $15 \mathrm{~min}$ whilst $71 \%$ still remained viable after $1 \mathrm{~h}$. This inhibitor had no effect upon the number of bacteria phagocytosed or upon degranulation. In a cell-free system, $2.5 \mu \mathrm{M}-\mathrm{H}_{2} \mathrm{O}_{2}$ alone killed $55 \%$ of the bacteria, whereas in the presence of myeloperoxidase (i.e. $10 \mathrm{mU}$ myeloperoxidase and $2.5 \mu \mathrm{M}-\mathrm{H}_{2} \mathrm{O}_{2}$ ) virtually all of the bacteria were killed: the addition of $50 \mu \mathrm{M}-\mathrm{SHAM}$ abolished this myeloperoxidase-enhanced killing but did not affect the $\mathrm{H}_{2} \mathrm{O}_{2}$-dependent killing. We therefore conclude that in normal neutrophils whilst $\mathrm{H}_{2} \mathrm{O}_{2}$ is required for killing of this pathogen, both myeloperoxidase-dependent and -independent pathways exist.
\end{abstract}

\section{INTRODUCTION}

In order to carry out their important role in host defence, polymorphonuclear leucocytes (neutrophils) possess a battery of cytotoxic enzymes and associated pathways which can be utilized for microbial killing. These may be classified as those whose activity is either dependent or independent of the requirement for molecular $\mathrm{O}_{2}$. The latter group includes the activities of proteases, defensins, permeability-inducing proteins and lysozyme (Elsbach \& Weiss, 1983; Spitznagel, 1984; Ganz et al., 1985). $\mathrm{O}_{2}$-dependent processes result in the generation of a series of reactive oxygen metabolites (e.g. $\mathrm{O}_{2}^{-}, \mathrm{H}_{2} \mathrm{O}_{2}, \cdot \mathrm{OH}, \mathrm{HOCl}$, and ${ }^{1} \mathrm{O}_{2}$ ) during a respiratory burst of non-mitochondrial $\mathrm{O}_{2}$ uptake (Babior, 1978, 1984). The possession of such a diverse array of bactericidal systems with different biochemical modes of action is necessary to ensure the maximal killing potential against a wide range of pathogens which may themselves show resistance to any one particular system. Indeed, experimental evidence has confirmed this selective toxicity: bacterial-permeability-inducing peptide preferentially kills Gram-negative bacteria such as Escherichia coli and Salmonella typhimurium (Elsbach \& Weiss, 1983), defensins are toxic to Cryptococcus neoformans and Pseudomonas aeruginosa (Ganz et al., 1985) and the efficient killing of Staphylococcus aureus requires the activation of $\mathrm{O}_{2}$-dependent processes (Edwards et al., 1987, 1988a,b).

The generation of a full complement of reactive oxidants by neutrophils requires the activities of two enzyme systems. Firstly, a plasma-membrane-bound NADPH oxidase is activated to

Abbreviation: SHAM, salicylhydroxamic acid. 
produce $\mathrm{O}_{2}^{-}$and $\mathrm{H}_{2} \mathrm{O}_{2}$ during the respiratory burst (Rossi, 1986) and, secondly, myeloperoxidase (an enzyme normally located within azurophilic granules and discharged to the site of oxidant generation by the process of degranulation; Klebanoff \& Clark, 1978), may react with $\mathrm{H}_{2} \mathrm{O}_{2}$ and possibly $\mathrm{O}_{2}^{-}$to produce $\mathrm{HOCl}$ and related compounds (Harrison \& Schultz, 1976). Since its discovery, myeloperoxidase has been shown to possess peroxidase, catalase, superoxide dismutase, oxidase and DNA-binding activities (Winterbourne et al., 1985; Cuperus et al., 1986; Edwards \& Lloyd, 1987; Murao et al., 1988) and, in vitro, the myeloperoxidase- $\mathrm{H}_{2} \mathrm{O}_{2}-$ halide system has potent antibacterial, antifungal, antiviral and antitumour properties (Klebanoff \& Clark, 1978). However, the role of this enzyme in bacterial killing has recently been questioned because of the finding that neutrophils from apparently healthy individuals may be deficient in this enzyme (Lehrer \& Cline, 1969; Salmon et al., 1970; Klebanoff \& Pincus, 1971; Nauseef, 1988). The degree of this deficiency varies but it must be borne in mind that in normal neutrophils this enzyme may constitute $5 \%$ of the total protein (Klebanoff \& Clark, 1978). Myeloperoxidase-deficient neutrophils have impaired ability to kill Candida and $S$. aureus in vitro (Kitahara et al., 1981 ; Parry et al., 1981; Lanza et al., 1987) and there is a close correlation between a deficiency in this enzyme and the occurrence of preleukaemia and neoplasms (Breton-Gorius et al., 1975; Lanza et al., 1987; Pui et al., 1987; Nauseef, 1988).

Since it has been proposed that in myeloperoxidase-deficient neutrophils other bactericidal systems are elaborated (Klebanoff \& Pincus, 1971; Kitahara et al., 1981), and also that a specific inhibitor does not exist (Edwards \& Swan, 1986), definition of the role of this enzyme in microbial and tumour cell killing by normal neutrophils has not as yet been possible. The most commonly used myeloperoxidase inhibitor in neutrophil studies is sodium azide, but since this is a non-specific haem inhibitor and also quenches $\cdot \mathrm{OH}$ and ${ }^{1} \mathrm{O}_{2}$ (Halliwell \& Gutteridge, 1985), its broad toxicity renders it useless for cytotoxicity studies. We have recently shown that salicylhydroxamic acid (SHAM), previously used as an inhibitor of the alternative cyanideinsensitive oxidase of plant mitochondria (Schonbaum et al., 1971) and some other redox enzymes (Rich et al., 1978), is a potent inhibitor of the myeloperoxidase system (Davies \& Edwards, 1989). The aim of the present study was to use this inhibitor to establish the role of myeloperoxidase in the killing of $S$. aureus by normal human neutrophils.

\section{METHODS}

Isolation and preparation of neutrophils. Polymorphonuclear leucocytes (neutrophils) were isolated from heparinized venous blood from healthy volunteers utilizing either a dextran/Ficoll sedimentation procedure (Edwards \& Swan, 1986) or Mono-Poly Resolving Medium (Flow Laboratories) as described previously (Edwards et al., 1987). After purification, cells were suspended in a buffer containing (mM): $\mathrm{NaCl}, 120 ; \mathrm{KCl}, 4 \cdot 8 ; \mathrm{KH}_{2} \mathrm{PO}_{4}$, $1 \cdot 2 ; \mathrm{CaCl}_{2}, 1 \cdot 3 ; \mathrm{MgSO}_{4}, 1 \cdot 2 ; \mathrm{HEPES}, 25(\mathrm{pH} 7 \cdot 4)$; and $0.1 \%$ bovine serum albumin. Neutrophils ( $>98 \%$ purity) were counted using a Fuchs-Rosenthal haemocytometer slide and used within $4 \mathrm{~h}$ of preparation.

Bactericidal assays. Staphylococcus aureus (Oxford) was grown overnight on nutrient agar plates and then opsonized with $10 \%(\mathrm{v} / \mathrm{v})$ pooled normal human serum by the method of Turner et al. (1986) as described in detail by Edwards et al. (1987). After opsonization, unbound proteins were removed by centrifugation and bacteria were suspended in sterile buffer at known concentrations. Opsonized bacteria $\left(3 \times 10^{7} \mathrm{ml}^{-1}\right)$ were incubated with neutrophil suspensions $\left(10^{6} \mathrm{ml}^{-1}\right)$ with gentle agitation in the presence or absence of SHAM at the stated concentration, and at suitable time intervals samples were removed for the estimation of viable bacteria as described previously (Edwards et al., 1987). Alternatively, opsonized bacteria were incubated in a cell-free myeloperoxidase $/ \mathrm{H}_{2} \mathrm{O}_{2}$ system (Klebanoff, 1968) containing $2.5 \mu \mathrm{M}-\mathrm{H}_{2} \mathrm{O}_{2}$ and $120 \mathrm{mM}-\mathrm{Cl}^{-}$in the presence or absence of $10 \mathrm{mU}$ purified myeloperoxidase and $50 \mu \mathrm{M}$-SHAM. Viable bacteria were then estimated after $30 \mathrm{~min}$ incubation.

Analytical methods. Chemiluminescence was measured using an LKB Wallac 1250 luminometer in neutrophil suspensions containing $10^{6}$ cells $\mathrm{ml}^{-1}$ and $10 \mu \mathrm{M}$-luminol: suspensions were stimulated by the addition of $4 \times 10^{9}$ latex beads $\mathrm{ml}^{-1}(1.01 \mu \mathrm{m}$ diameter $)$ or opsonized bacteria $\left(3 \times 10^{7} \mathrm{ml}^{-1}\right)$ in the presence or absence of SHAM at the stated concentration. Human myeloperoxidase was purified from buffy coats as described by Pember $e t$ al. (1983) and had an $A_{430} / A_{280}$ ratio of 0.68 .

Electron microscopy. Neutrophils incubated with opsonized $S$. aureus in the presence or absence of $50 \mu \mathrm{M}$-SHAM for $20 \mathrm{~min}$ at $37^{\circ} \mathrm{C}$ were fixed in cold $0.15 \mathrm{M}$-cacodylate-buffered glutaraldehyde, $\mathrm{pH} 7.4(2.5 \%$, v/v) and post- 
fixed with osmium tetroxide $(1 \%, v / v)$. The mixtures were embedded in Araldite, thin-sectioned and stained with Reynold's lead citrate and uranyl acetate $(1 \%, \mathrm{w} / \mathrm{v})$. Thin sections were examined using a Philips 301 electron microscope.

Statistical analysis. Data were compared using Student's $t$-test.

Chemicals. Luminol, HEPES and SHAM were from Sigma. All other chemicals were of the highest purity available.

\section{RESULTS AND DISCUSSION}

\section{Effect of SHAM on chemiluminescence during phagocytosis}

In order to establish that SHAM permeated neutrophils and inhibited myeloperoxidase activity within phagolysosomes, neutrophils were incubated with various concentrations of inhibitor and the chemiluminescence stimulated upon phagocytosis was measured. As shown in Fig. 1, $50 \mu \mathrm{M}$-SHAM inhibited the chemiluminescence stimulated during phagocytosis of opsonized $S$. aureus by over $60 \%$ and that measured during phagocytosis of unopsonized latex beads by over $80 \%$. Since SHAM did not inhibit uptake of particles (see later) and as it has no inhibitory effect on oxidant generation (Davies \& Edwards, 1989), these data show that this compound effectively inhibited the intraphagosomal activity of myeloperoxidase after both receptor-dependent and -independent uptake of particles.

\section{Effect of SHAM on the killing of S. aureus by neutrophils}

Since $50 \mu \mathrm{M}$-SHAM resulted in considerable inhibition of intraphagosomal myeloperoxidase activity (Fig. 1), we determined whether this inhibition resulted in impaired bactericidal activity towards $S$. aureus. Neutrophil suspensions were incubated with opsonized $S$. aureus in the presence or absence of $50 \mu \mathrm{M}$-SHAM. At suitable time intervals after the addition of luminol and bacteria, portions were removed for estimation of viable bacteria (after lysis of neutrophils) and measurement of chemiluminescence (Fig. 2). In control suspensions the bacteria were rapidly killed during phagocytosis; in suspensions treated with $50 \mu \mathrm{M}-\mathrm{SHAM}$, killing was clearly reduced. For example, after 15 min incubation with the inhibitor, $87 \%( \pm 10$; mean $\pm S D$, $n=7$ ) remained viable, compared to $56 \%( \pm 9, n=9)$ in the control, and by $60 \min 71 \%$ were viable $( \pm 11, n=10)$ compared to $43 \%( \pm 8, n=10)$ in control suspensions. Control experiments showed that this concentration of inhibitor alone had no effect on the viability of the bacteria.

Luminol-dependent chemiluminescence traces obtained from these experiments are shown in Fig. 3. In control suspensions the maximum rate of increase in chemiluminescence occurred within the first 15-20 min (corresponding to the time of greatest killing) and then slowly declined over the remainder of the experiment after reaching a maximum value of about $70 \mathrm{mV}$. In identical suspensions treated with $50 \mu \mathrm{M}$-SHAM, the maximum rate of chemiluminescence was $15 \mathrm{mV}$ at $20 \mathrm{~min}$ and after this time the rate slowly declined.

Samples were fixed with glutaraldehyde $30 \mathrm{~min}$ after phagocytosis of $S$. aureus and electron micrographs analysed in order to assess whether SHAM had any effect upon the rate of particle uptake or degranulation. Enumeration of intracellular, phagocytosed bacteria in these micrographs revealed no significant difference in the rate of particle uptake in control (7.6 \pm 4.9 bacteria per neutrophil; mean $\pm \mathrm{SD}, n=101$ neutrophils counted) or SHAM-treated suspensions $(7.6 \pm 4.2$ bacteria per neutrophil, $n=102$ neutrophils counted). Furthermore, these experiments showed that migration of granules towards the phagosome and degranulation were not affected by treatment with this compound (Fig. 4). Thus, we attribute the reduced killing (Fig. 2) to inhibition of myeloperoxidase and not to any effect of SHAM on phagocytosis or degranulation.

Effect of $\mathrm{SHAM}$ on the killing of $\mathrm{S}$. aureus by a cell-free myeloperoxidase $/ \mathrm{H}_{2} \mathrm{O}_{2}$ system

We have previously shown that SHAM has no effect on the kinetics of oxidant generation during the respiratory burst (Davies \& Edwards, 1989). However, in order to exclude the possibility that this compound affected $\mathrm{H}_{2} \mathrm{O}_{2}$-dependent (but myeloperoxidase-independent) 


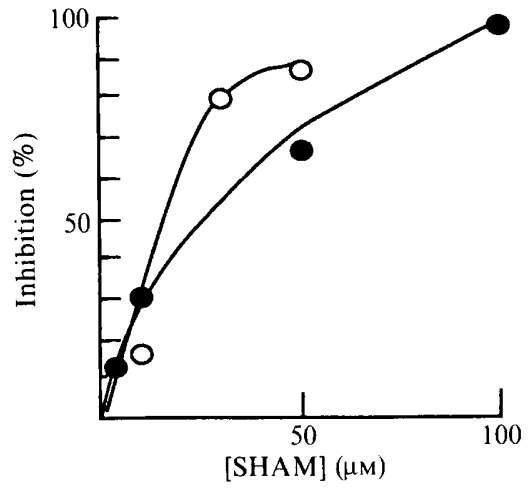

Fig. 1

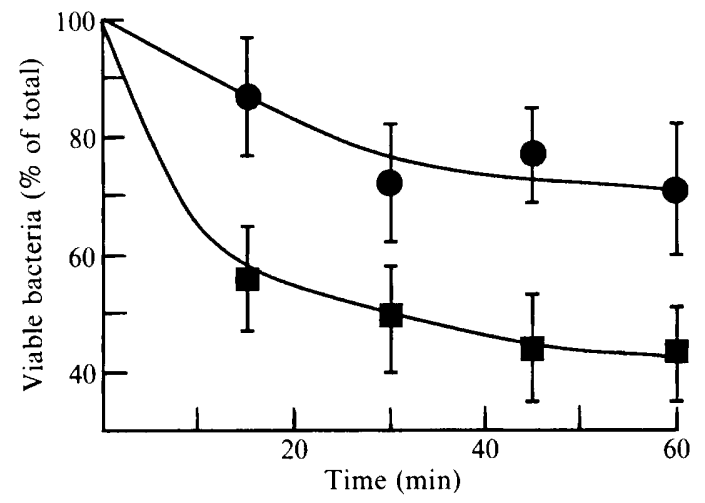

Fig. 2

Fig. 1. Effect of SHAM on chemiluminescence during phagocytosis. Suspensions of neutrophils $\left(10^{6}\right.$, total volume $1 \mathrm{ml}$ ) were incubated at $37^{\circ} \mathrm{C}$ with $10 \mu \mathrm{M}$-luminol in the presence or absence of SHAM at the stated concentration. Phagocytosis was then stimulated by the addition of either $3 \times 10^{7}$ opsonized $S$. aureus $(O)$ or $4 \times 10^{9}$ unopsonized latex beads $(O)$ and the chemiluminescence response measured.

Fig. 2. Effect of SHAM on the killing of $S$. aureus by neutrophils. Suspensions of neutrophils $\left(10^{6}\right.$, total volume $1 \mathrm{ml}$ ) were incubated at $37^{\circ} \mathrm{C}$ in the presence $(O)$ or absence $(\square)$ of $50 \mu \mathrm{M}$-SHAM. At time zero, $3 \times 10^{7}$ opsonized $S$. aureus were added to the suspensions and portions removed at intervals for estimation of viable bacteria. Results presented are means of at least seven experiments, with error bars representing standard deviations.

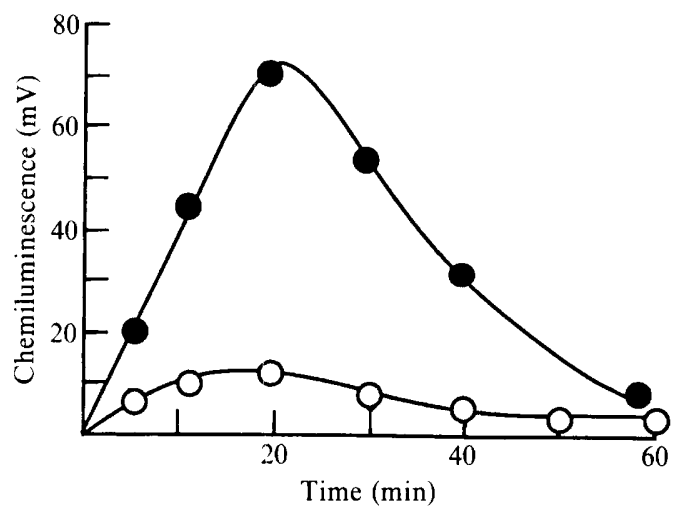

Fig. 3. Luminol-dependent chemiluminescence during killing of $S$. aureus. Suspensions of neutrophils $\left(10^{6}\right.$, total volume $1 \mathrm{ml}$ ) containing $10 \mu \mathrm{M}$-luminol were incubated at $37^{\circ} \mathrm{C}$ in the presence $(\mathrm{O})$ or absence (O) of $50 \mu \mathrm{M}$-SHAM. At time zero, $3 \times 10^{7}$ opsonized $S$. aureus were added and the chemiluminescence response measured at time intervals. Results presented are typical of at least seven experiments.

killing of $S$. aureus, the killing of opsonized bacteria in a cell-free myeloperoxidase $/ \mathrm{H}_{2} \mathrm{O}_{2}$ system (see Methods) was examined. When opsonized bacteria were incubated with $2 \cdot 5 \mu \mathrm{M}-\mathrm{H}_{2} \mathrm{O}_{2}$ alone, $55 \%( \pm 20$; mean $\pm \mathrm{SEM}, n=8)$ of the bacteria were killed within 30 min incubation. In suspensions containing $10 \mathrm{mU}$ purified myeloperoxidase plus $2.5 \mu \mathrm{M}-\mathrm{H}_{2} \mathrm{O}_{2}$, considerably more bacteria were killed $(95 \% \pm 19, n=11)$, i.e. the purified enzyme enhanced $\mathrm{H}_{2} \mathrm{O}_{2}$-dependent killing of this organism. However, in suspensions containing $10 \mathrm{mU}$ purified myeloperoxidase, $2.5 \mu \mathrm{M}-\mathrm{H}_{2} \mathrm{O}_{2}$ plus $50 \mu \mathrm{M}$-SHAM, the level of killing $(44 \% \pm 7, n=9)$ was similar to that observed by $\mathrm{H}_{2} \mathrm{O}_{2}$ alone, i.e. the inhibitor abolished the myeloperoxidase-enhanced killing.

The results of these experiments are consistent with previous reports regarding the mechanisms of killing of $S$. aureus by human neutrophils and show several important features. 


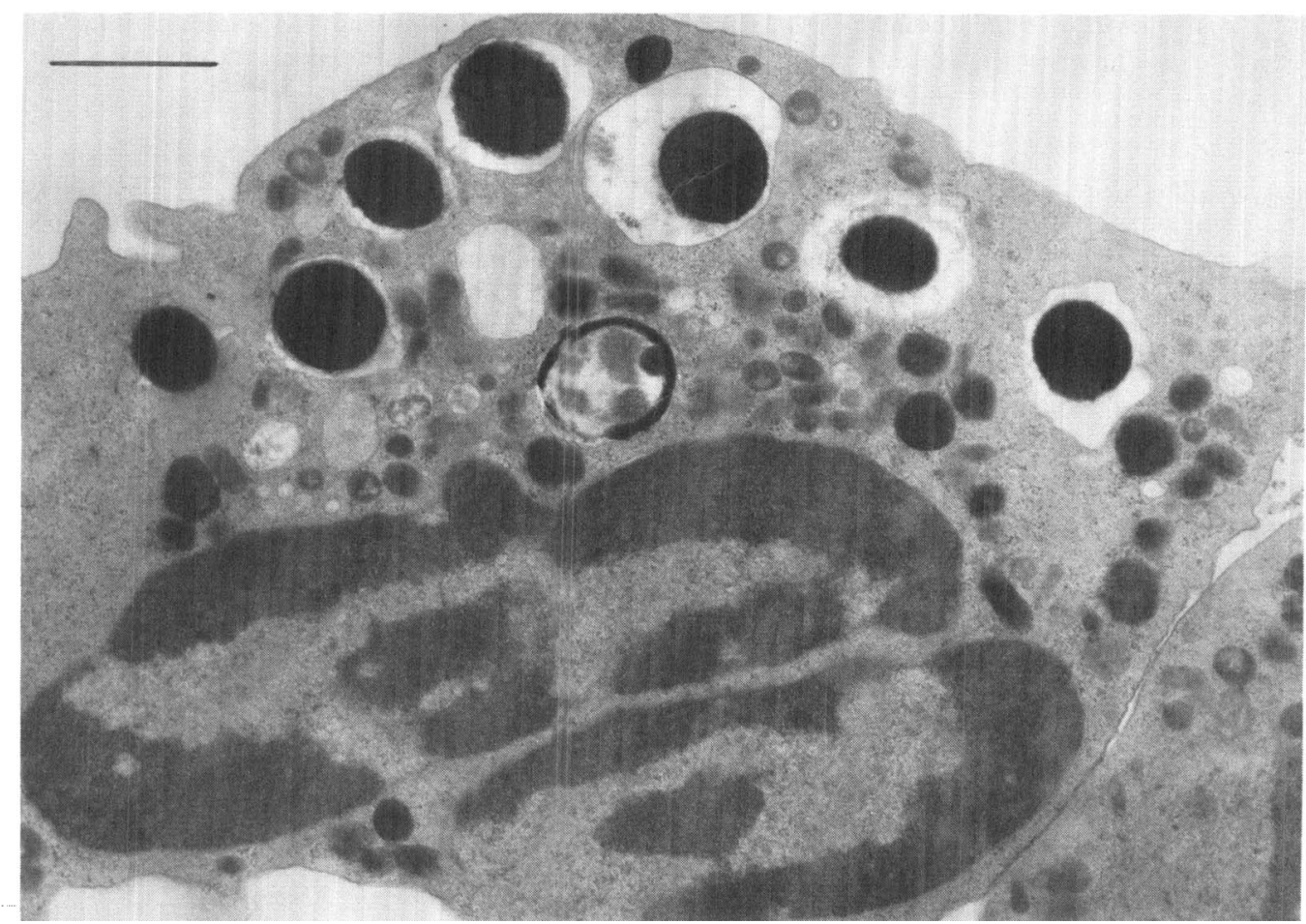

Fig. 4. Electron micrograph of ingested $S$. aureus. Neutrophils were incubated as described in the legend to Fig. 2. After $20 \mathrm{~min}$ incubation with opsonized $S$. aureus, suspensions were fixed with glutaraldehyde as described in Methods. After embedding, sectioning and staining at least 100 neutrophils from control or SHAM-treated suspensions were examined and the numbers of ingested bacteria counted. The figure shows a section of a neutrophil that had been incubated with $50 \mu \mathrm{M}-\mathrm{SHAM}$ before the addition of bacteria. Bar, $1 \mu \mathrm{m}$.

Firstly, $\mathrm{H}_{2} \mathrm{O}_{2}$ (in the absence of myeloperoxidase) is capable of killing this pathogen. Secondly, the $\mathrm{H}_{2} \mathrm{O}_{2}$-dependent killing of this organism is considerably enhanced by the presence of myeloperoxidase. Thirdly, oxygen-independent granule enzymes do not play a role in this killing process since neutrophils from patients with chronic granulomatous disease cannot kill this pathogen (Edwards et al., 1987): the only biochemical defect in these patients is their inability to generate reactive oxidants (Tauber et al., 1983). Thus, we confirm that the efficient killing of $S$. aureus by human neutrophils requires the activation of oxygen-dependent processes (Edwards $e t$ $a l ., 1987,1988 a, b)$ but now show that both myeloperoxidase-dependent and -independent pathways exist.

SHAM can act as a peroxidase inhibitor and (at a concentration of $50 \mu \mathrm{M}$ ) scavenge the myeloperoxidase product $\mathrm{HOCl}$ (Davies \& Edwards, 1989). Therefore, its ability to reduce bacterial killing may reside in its ability to either inhibit the enzymic activity of myeloperoxidase or else scavenge one of its major products, or a combination of these two effects. The use of SHAM as an inhibitor of myeloperoxidase has, for the first time, enabled the role of this enzyme in $S$. aureus killing by normal neutrophils to be evaluated. The data presented here confirm the observations of experiments with myeloperoxidase-deficient neutrophils which could not kill this pathogen as efficiently as controls (Kitahara et al., 1981; Lanza et al., 1987). Thus, by virtue of its non-toxicity towards the target cell, SHAM is a powerful analytical tool which can now be used to delineate the function of myeloperoxidase in other inflammatory events. 
We thank the Arthritis and Rheumatism Council, Mersey Regional Health Authority and North West Cancer Research Fund for generous financial support and Lynn Chattings for excellent technical assistance.

\section{REFERENCES}

BABIOR, B. M. (1978). Oxygen-dependent killing by phagocytes. New England Journal of Medicine 298, 659-668.

BABIOR, B. M. (1984). The respiratory burst of phagocytes. Journal of Clinical Investigation 73, 599601.

Breton-Gorius, J., Houssay, D. \& Dreyfus, B. (1975). Partial myeloperoxidase deficiency in a case of preleukaemia. 1. Studies of fine structure and peroxidase synthesis of promyelocytes. British Journal of Haematology 30, 273-278.

Cuperus, R. A., MuiJsers, A. O. \& WeVer, R. (1986). The superoxide dismutase activity of myeloperoxidase: formation of compound III. Biochimica et biophysica acta 871, 78-84.

DAviEs, B. \& EDWARDS, S. W. (1989). Inhibition of myeloperoxidase by salicylhydroxamic acid. Biochemical Journal 258, 801-806.

EDWARDS, S. W. \& LLOYD, D. (1987). CO-reacting haemoproteins of neutrophils: evidence for cytochrome $b-245$ and myeloperoxidase as potential oxidases during the respiratory burst. Bioscience Reports 7, 193-199.

EDWARDS, S. W. \& SWAN, T. F. (1986). Regulation of superoxide generation by myeloperoxidase during the respiratory burst of human neutrophils. Biochemical Journal 237, 601-604.

Edward, S. W., SAY, J. E. \& Hart, C. A. (1987). Oxygen-dependent killing of Staphylococcus aureus by human neutrophils. Journal of General Microbiology 133, 3591-3597.

EdWARd, S. W., SAY, J. E. \& Hughes, V. (1988a). Gamma interferon enhances the killing of Staphylococcus aureus by human neutrophils. Journal of General Microbiology 134, 37-42.

Edwards, S. W., Hart, C. A., Davies, J. M., Pattison, J., Hughes, V. \& Sills, J. A. (1988b). Impaired neutrophil killing in a patient with defective degranulation of myeloperoxidase. Journal of Clinical and Laboratory Immunology 25, 201-206.

ElsBACH, P. \& WEISS, J. (1983). A reevaluation of the role of the $\mathrm{O}_{2}$-dependent and $\mathrm{O}_{2}$-independent microbial systems of phagocytes. Reviews of Infectious Diseases 5, 843-853.

Ganz, T., Selsted, M. E., Szklarek, D., Harwig, S. S. L., DAHER, K., BaINTON, D. F. \& LeHRER, R. I. (1985). Defensins: natural peptide antibiotics of human neutrophils. Journal of Clinical Investigation 76, 1427-1435.

Halliwell, B. \& Gutteridge, J. M. C. (1985). Free Radicals in Biology and Medicine. Oxford: Clarendon Press.

Harrison, J. E. \& Schultz, J. (1976). Studies on the chlorinating activity of myeloperoxidase. Journal of Biological Chemistry 251, 1371-1374.

Kitahara, M., Eyre, H. J., Simonian, Y., Atkin, C. L. \& HASSTEDT, S. J. (1981). Hereditary myeloperoxidase deficiency. Blood 57, 888-893.

KLEBANOFF, S. J. (1968). Myeloperoxidase-halidehydrogen peroxide antibacterial system. Journal of Bacteriology 95, 2131-2138.
Klebanoff, S. J. \& Clark, R. A. (1978). The Neutrophil: Function and Clinical Disorders. Amsterdam: North-Holland.

Klebanoff, S. J. \& Pincus, S. H. (1971). Hydrogen peroxide utilization in myeloperoxidase-deficient leukocytes: a possible microbicidal control mechanism. Journal of Clinical Investigation 50, 2226-2229.

Lanza, F., Fietta, A., Spisani, S., Castoldi, G. L. \& Traniello, S. (1987). Does a relationship exist between neutrophil myeloperoxidase deficiency and the occurrence of neoplasms? Journal of Clinical and Laboratory Immunology 22, 175-180.

LeHReR, R. I. \& Cline, M. J. (1969). Leukocyte myeloperoxidase deficiency and disseminated candidiasis: the role of myeloperoxidase in resistance to Candida infections. Journal of Clinical Investigation 48, 1478-1488.

Murao, S. I., Stevens, S. J., Ito, A. \& Huberman, E. (1988). Myeloperoxidase: a myeloid cell nuclear antigen with DNA binding properties. Proceedings of the National Academy of Sciences of the United States of America 85, 1232-1236.

NAUSEEF, W. M. (1988). Myeloperoxidase deficiency. In Phagocytic Defects 1: Abnormalities Outside of the Respiratory Burst, pp. 135-158. Edited by J. T. Curnutte. Philadelphia: W. B. Saunders.

Parry, M. F., Root, R. K., Metcalf, J. A., Delaney, K. K., Kaplow, L. S. \& RichaR, W. J. (1981). Myeloperoxidase deficiency. Prevalence and clinical significance. Annals of Internal Medicine 95, 293301.

Pember, S. O., Shapira, R. \& Kinkade, J. M., JR (1983). Multiple forms of myeloperoxidase from human neutrophilic granulocytes: evidence for differences in compartmentalization, enzymatic activity and sub-unit structure. Archives of Biochemistry and Biophysics 221, 391-403.

Pui, C.-H., Behm, F. G., Kalwinsky, D. K., Murphy, S. B., Butler, D. L., Dahl, G. V. \& Mirro, J. (1987). Clinical significance of low levels of myeloperoxidase positivity in childhood acute nonlymphoblastic leukemia. Blood 70, 51-54.

Rich, P. R., Wiegand, N. K., Blum, H., Moore, A. L. \& BonNER, W. D., JR (1978). Studies on the mechanism of inhibition of redox enzymes by substituted hydroxamic acids. Biochimica et biophysica acta 525, 325-337.

Rossi, F. (1986). The $\mathrm{O}_{2}^{-}$forming NADPH oxidase of the phagocytes: nature, mechanisms of activation and function. Biochimica et biophysica acta 853, 6589.

Salmon, S. E., Cline, M. J., Schultz, J. \& Lehrer, R. I. (1970). Myeloperoxidase deficiency. Immunological study of a genetic leukocyte defect. New England Journal of Medicine 282, 250-253.

SChONBaum, G. R., Bonner, W. D., JR, STOREy, B. T. \& BAHR, J. T. (1971). Specific inhibition of the cyanide-insensitive respiratory pathway in plant mitochondria by hydroxamic acids. Plant Physiology 47, 124-128.

SPITZNAGEL, J. K. (1984). Nonoxidative antimicrobial 
systems in leucocytes. In Regulation of Leukocyte Function (Contemporary Topics in Immunology vol. 14), pp. 234-283. Edited by R. Snyderman. New York: Plenum.

Tauber, A. I., BorregaArd, N., Simons, E. \& WRIGHT, J. (1983). Chronic granulomatous disease: a syndrome of phagocyte oxidase deficiencies. Medicine 62, 286-309.

Turner, M. W., Grant, C., Seymour, N. D., HARVEY, B. \& LEVINSKY, R. J. (1986). Evaluation of
$\mathrm{C} 3 \mathrm{~b} / \mathrm{C} 3 \mathrm{bi}$ opsonization and chemiluminescence with selected yeasts and bacteria using sera of different opsonic potential. Immunology 58, 111-115.

Winterbourne, C. C., Garcia, R. C. \& Segal, A. W. (1985). Production of the superoxide adduct of myeloperoxidase (compound III) by stimulated human neutrophils and its reactivity with hydrogen peroxide and chloride. Biochemical Journal 228, 583592. 